\title{
The Positioning of Mauritius as the Gateway to African Investments after the Review of the Mauritius- India Double Taxation Agreement
}

\author{
Adjnu Damar Ladkoo (Corresponding author) \\ Dept. of Management, University of Mauritius, Reduit, Mauritius \\ Tel: 230-403-7563Ｅ-mail: a.ladkoo@uom.ac.mu
}

\author{
Shweta Riddhimah Dhurmah \\ Mauritius \\ E-mail: shweta.dhurmah@ outlook.com
}

Received: March 14, 2018 Accepted: March 27, 2018 Published: X, 2018

doi:10.5296/ber.v8i2.12965

URL: https://doi.org/10.5296/ber.v8i2.12965

\begin{abstract}
This paper investigates whether the re-negotiation of the Mauritius-India double taxation avoidance agreements will have an impact on the treaties between Mauritius and the African continent. The methodology explored the reasons for the re-negotiation and analysed impact of re-negotiation. The research findings showed that treaty shopping, loss of revenue, round tripping or abuse by Indians, controversy around the residency status or the meaning of permanent establishment, money laundering control in India, improved regulatory framework for attracting investments directly and too much Foreign Direct investment from Mauritius into the Indian economy were the main reasons for re-negotiation of the treaty.
\end{abstract}

Keywords: Mauritius, India, African, Investments, Taxation, Agreement, Avoidance, Treaty

\section{Introduction}

Mauritius is considered to be the success story of the African continent with its favourable investment climate, political and social stability, which makes it a destination of choice for those wishing to invest in Africa by using the Mauritian financial sector as a cross border platform. Although Mauritius has the potential to become the 'gateway to Africa' and act as a regional International Financial Center, it is of utmost significance to assess the impact of the re-negotiations of the Mauritius-India Double Taxation Avoidance Agreement on those that 
Mauritius has with the African continent. The tax treaty between India and Mauritius was signed in 1982 in keeping with India's strategic interests in the Indian Ocean and India's close cultural links with Mauritius whereby the treaty provides for a capital gains tax exemption to a Mauritius resident on transfer of Indian securities (Forbes India, 2016). This study aims to contribute new and unique evidence to the debates surrounding Double Taxation Avoidance Agreement between Mauritius and India and African countries. Previous work has concentrated on Double Taxation Avoidance Agreement between Mauritius and India; however, this study aims to analyse the impact of the renegotiation of this Double Taxation Avoidance Agreement on those that Mauritius has with African countries. The African Continent is of great concern for many countries due to the possibility for massive investment in the latter across several industries. The paper should be of interest to readers in the areas of finance, tax, business development and marketing. The objectives were set as follows:

(a) Identify the benefits of the Mauritius-India Double Taxation Avoidance Agreement to each country;

(b) Analyze the possible reasons for the re-negotiation of the Mauritius-India Double Taxation Avoidance Agreement;

(c) Assess the possible impact of such re-negotiation on the Double Taxation Avoidance Agreement that Mauritius has with the African continent;

(d) Recommend measures that should be taken by Mauritius to mitigate any impact.

It is however beyond the scope of this study to examine the impact of Foreign Direct Investment inflows from India through Mauritius into Africa as a result of the re-negotiation of the Mauritius-India Double Taxation Avoidance Agreement. The study will rather emphasise on the impact of the use of Mauritian companies holding Global Business License for making investment into Africa, irrespective of the countries of origin. Most studies in the field of Double Taxation Avoidance Agreement have only focused on the characteristics, benefits and re-negotiation of the Mauritius-India Double Taxation Avoidance Agreement. This indicates a need to understand to what extent the re-negotiations will affect the use of Mauritian intermediaries for investment into Africa.

\section{Literature Review}

\subsection{Mauritius Double Taxation Avoidance Agreements}

Mauritius has focused the development of its global business centre on the use of its growing network of double-taxation treaties. Substantial foreign investment has been channeled through Mauritian entities and this is expected to increase as the Mauritius treaty network expands and as investment prospects in the region flourish (Mauritius Offshore Business Activities Authority, 1998). According to McGhee (1997), Double Taxation Avoidance Agreement are agreements between two countries which mainly allow tax which is deducted at source from payments from one country to be compensated against the tax which would have been payable by the non-resident taxpayer. Blonigen and Davies (2004) outlined four main functions of Double Taxation Avoidance Agreement, firstly, to homogenise tax definitions of treaty partners since differing tax definitions can end into double taxation and 
inefficient capital flows. Secondly, it is to prevent tax avoidance. The third purpose of tax treaties is to restrict treaty shopping. In fact, the most common rules regarding treaty shopping restrict treaty benefits if more than $50 \%$ of a corporation's stock is held by a third, non-treaty country's resident (Doernberg, 1997). Finally, tax treaties affect the actual taxation of multinational corporations through the provision of double taxation relief and the rules that minimise maximum allowable withholding taxes on dividend, interest and royalty. A resident corporation wishing to avail itself to the benefits of a tax treaty will therefore apply to the Mauritius Revenue Authority to obtain a Tax Residence Certificate issued by the Director General under the recommendation of the Financial Services Commission of Mauritius. The corporate tax in Mauritius is $15 \%$, a global category 1 company benefits from a deemed foreign tax credit of eighty-percent of the tradable profits, such that the net tax is three-percent of the taxable profits. In the event that the company can show evidence that the foreign tax suffered is greater than twelve percent, then the amount of foreign tax can be claimed as a tax credit against tax payable up to a maximum of fifteen percent (Income Tax Act, 1995). ${ }^{1}$ The rule of residence for accessing the Double Taxation Avoidance Agreement is covered by Section 73(1) (b) of the Mauritius Income Tax Act, which stipulates that the central management and control of the company must be in Mauritius. There are several conditions prescribed that should simply be fulfilled before the tax authorities consider the central management and control of the company to be in Mauritius ${ }^{2}$. The vast majority of Double Taxation Avoidance Agreement are based more on the Organisation for Economic Co-operation and Development model (Arnold et al., 2001), which is the case for Mauritius' treaties that also contain exchange of information clauses; although, the exchange is limited to matters concerning the working of the treaties themselves. Currently, Mauritius has concluded 37 treaties and is party to a series of treaties under negotiation.

\subsection{Double Taxation Avoidance Agreement between Mauritius and India}

The Double Taxation Avoidance Agreement between India and Mauritius was entered into on 24 August 1982 and formally came into force through a Notification No. GSR 920 (E) dated December 6, 1983. The purpose of such a tax treaty was to avoid double taxation and prevent fiscal evasion with respect to taxes on income and capital gains and for the encouragement of mutual trade and investment (Patel, 2008). With the help of this treaty, Mauritius was able to call the financial services its most important economic activity after tourism. India has more than 50 agreements of this nature with different countries, 16 of which are identical to the one signed with Mauritius. But Mauritius seems to be the preferred route for investments to India for a range of reasons (Thakurta, 2004).

\subsection{Importance of the Mauritius-India Double Taxation Avoidance Agreement to Mauritius}

For almost 10 years, the Double Taxation Avoidance Agreement existed only on paper as foreign investors were not allowed to invest in Indian stock markets. It was only around 1992 that foreign institutional investors were allowed to invest in the Indian stock markets. At the

\footnotetext{
${ }^{1}$ Income Tax Act 1995 (Consolidate version with amendments up to 17 April 2012)

2 International Tax Planning of Collaborations with Foreign Companies, Illustration of treaty shopping through Mauritius
} 
same time, the Government of Mauritius passed the Offshore Business Activities Act, which allowed foreign companies to register in Mauritius for investing abroad (Siddaiah, 2010). A resident corporation, which proposes to conduct business outside Mauritius and wishing to avail itself to the benefits of the Double Taxation Avoidance Agreement, will apply for a Global Business Licence 1. According to Titus and Johnston (2006), the liberalization of tax regimes and signing of Double Taxation Avoidance Agreement based on the Organisation for Economic Co-operation and Development model treaty yielded fruit; many of the companies, trusts and mutual funds operating in Mauritius, holding a Global Business Licence and taking advantage of the Double Taxation Avoidance Agreement, have made substantial investments. Ruding (1992) supported that taxation plays little part in the initial investment decision, play important role in location decisions, more important role for some types of investment and are growing in importance. The impact of Mauritius-India Double Taxation Avoidance Agreement has been much more favourable than generally expected. The network of Double Taxation Avoidance Agreement, coupled with a low-tax regime for the global business sector, as well as regional knowledge and cultures, have been instrumental in attracting large numbers of foreign investments to Mauritius (Campbel, 2008). In fact, the financial services sector in Mauritius has enjoyed remarkable success over the last two decades and has become one of the main pillars of the Mauritian economy, currently contributing around $12 \%$ to gross domestic product (Board of Investment, 2013). The World Investment Report 2012 indicates that Foreign Direct Investment inflows and outflows in Mauritius amounted to US\$ 273 million and US\$ 89 million respectively for the year 2011 as compared to the annual average of US\$ 162 million and US\$ 39 million respectively for the pre-crisis period 2005-2007.

\subsection{Importance of the Mauritius-India Double Taxation Avoidance Agreement to India}

Investors have been known to go so far as to quickly set up corporations in countries with no connection to themselves or to target country, simply to take advantage of a particular treaty network (Van Weeghel, 1998). In order to benefit from the features of the Double Taxation Avoidance Agreement between Mauritius and India, investors, instead of investing directly into India, use a Global Business Company 1 to make equity and debt investments into India. Hampton and Abbott (1999) supported that many multinational corporations have used Mauritius to route their investments into emerging regions through the use of Global Business Licence 1 (Mark et al., 1999). Although tax is considered a less important factor when compared to other important factors, taxation is a significant factor and sometimes even a major factor in location decisions (Devereux and Pearson, 1989).

\subsection{Foreign Direct Investments}

Mauritius is considered to be a global business center (Noshir et al., 2002) and according to the World Bank report "Investing Across Borders" (published in July 2010), Mauritius has one of the world's most open economies to foreign ownership and one of the highest recipients of Foreign Direct Investment per capita. Accordingly, the Mauritius-India Double Taxation Avoidance Agreement has played an important role in facilitating foreign investment in India (Siddaiah, 2010). Empirical studies have been conducted to find out whether a Double Taxation Avoidance Agreement has an impact on the level of cross-border investment. 


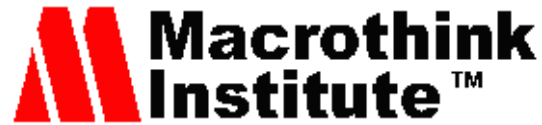

Business and Economic Research ISSN 2162-4860 2018, Vol. 8, No. 2

Trevino (2002) found that Double Taxation Avoidance Agreement between nations lead to higher Foreign Direct Investment flows. Barthel, Busse and Neumayer (2009) supported that Double Taxation Avoidance Agreement has been a successful tool in promoting Foreign Direct Investment. Stein and Daude (2007) also supported that tax treaty increases Foreign Direct Investment. The past decade has thus seen a significant increase in economic research studying the effect of double taxation conventions on Foreign Direct Investment, for example Blonigen and Davies, R.B., 2004; Davies, R.B., 2004; Egger et al., 2006. Indian government policy towards Foreign Direct Investment has evolved over time in tune with the requirements of the process of development in different phases (Kumar, 1998b). Investments have provided double the amount of capital that the equity markets have been able to provide to Indian corporates (Leeds, 2012). Borensztein et al (1998) empirically demonstrated that, subject to the threshold level of human capital availability in a developing country, Foreign Direct Investment leads to faster growth of the economy as compared to the domestic investment. Te Velde and Morissey (2002) demonstrated convincingly using a sample of Asian and African countries that Foreign Direct Investment leads to economic development in developing countries. According to the Department of Industrial Policy and Promotion of India, the country has received a maximum Foreign Direct Investment from Mauritius amounting to US\$ 73.67 billion (38.11\% of the total Foreign Direct Investment inflows) for the period April 2000 to March 2013. The emergence of Mauritius as the largest source of Foreign Direct Investment can be explained by the Double Taxation Avoidance Agreement signed between Mauritius and India that enables foreign investors to minimize their tax liability (Mahendra and Chandrasekhara, 2009).

\subsection{Investment Promotion and Protection Agreement}

Parikh, Jain and Spahr (2011), using a coordinated portfolio investment survey dataset from the International Monetary Fund covering 37 host countries from all continents and 50 source countries, studied differences between host and source country corporate income tax structures. They found that although Double Taxation Avoidance Agreement reduces the problem of double taxation to investors, tax matters is not the only factor that affects investors' decisions to invest. A Mauritian company has access to the strong network of Double Taxation Avoidance Agreement and Investment Promotion and Protection Agreement that Mauritius has with numerous countries. Investment Promotion and Protection Agreement offers security to investors, which make it both an attractive and competitive platform to invest in India. It allows for investment protection and security against expropriation as well as dispute resolution across 38 countries, including India (Gokool, 2012). Investment Promotion and Protection Agreement typically offer the following guarantees to investors (Board of Investment Mauritius, 2013).

(a) Free repatriation of investment capital and returns;

(b) Guarantee against expropriation;

(c) Most favoured nation rule with respect to the treatment of investment, compensation for losses in case of war or armed conflict or riot etc; 
(d) Arrangement for settlement of disputes between investors and the contracting states.

The Governments of Mauritius and India have recognized that the promotion and reciprocal protection of investments will lead to greater stimulation to the development of business initiatives in their territories ${ }^{3}$, hence, Investment Promotion and Protection Agreement allow country risk, which is the main challenge and obstacle for many countries, to be mitigated to a great extent (Srivastava, 2013).

\subsection{Double Taxation Avoidance Agreement between Mauritius and African Countries}

Currently, Mauritius has 13 treaties in force with African countries (Mozambique, Zimbabwe, Madagascar, Namibia, Rwanda, Swaziland, Botswana, Lesotho, Senegal, South Africa, Uganda, Kenya and Zambia). Some specific advantages for a company benefiting from the Double Taxation Avoidance Agreement with an African country as per Gokool (2012) are:

(a) Capital gain tax, where imposed in Africa, is generally levied at a rate ranging from 30-35\%. However, the Double Taxation Avoidance Agreements in force in Mauritius restrict taxing rights of capital gains to the country of residence of the seller of the assets. Since there is no capital gain tax in Mauritius, the potential tax savings for the Mauritius registered entity are significant.

(b) The majority of African states impose some withholding tax on dividends paid out to non-residents. These vary between $10 \%$ and 20\%. The Double Taxation Avoidance Agreement in force in Mauritius limits withholding tax on dividends. The treaty rates are generally $0 \%, 5 \%$ or $10 \%$ thereby creating potential tax savings of $5 \%$ to $20 \%$ depending on the investee country.

(c) With respect to capital gain tax, the Double Taxation Avoidance Agreement guarantee the maximum effective withholding tax rate should changes occur in the fiscal policy in the countries of investment.

According to figures from the Financial Services Commission, the share of total investment in the global business sector from Mauritius to African countries has grown from $8.7 \%$ to 10.3\%. Investment to Africa increased from US\$ 16 billion in 2009 to US\$ 27 billion in 2010. McKenzie et al. (2010) claimed that the increase in Africa's productivity indicate that African countries are gradually improving conditions to attract more productivity-enhancing investment. Moreover, Yang and Gupta (2005) observed that Africa is home to some 30 regional trade arrangements, many of which are part of deeper regional integration schemes. On average, each African country belongs to four Regional Trade Agreements (World Bank, 2004). Leveraging on its strategic and geographical proximity with Africa, Mauritius can be one of the best investment platforms for the region. Its membership to regional trading blocs, like the African Growth and Opportunity Act, Southern African Development Community and Common Market for Eastern and Southern Africa, allows Mauritian companies to benefit

\footnotetext{
3 Agreement for the Promotion and reciprocal protection of investments between the Government of the Republic of Mauritius and the Government of the Republic of India, signed on 04.09.1998 and entered into force on 20.06.2000
} 
from preferential access to an immediate market of more than 600 million people (Mauritius the Access Centre for Africa, April 2013). Being a member of these organisations, and with its favourable African Double Taxation Avoidance Agreement, Mauritius can therefore be used by the corporations and multinationals as platform for penetrating the African markets.

\subsection{Re-Negotiations of the Mauritius-India Double Taxation Avoidance Agreement}

Over the past decade, the Mauritius-India Double Taxation Avoidance Agreement has been subject to significant controversies, which first arouse when the Central Board of Direct Taxes issued a Circular No. 78 with regard to the issuance of a residency certificate by the Mauritian authorities (Patel, 2008). According to Siddaiah (2010), the Mauritius-India Double Taxation Avoidance Agreement has come under criticism for encouraging round-tripping and treaty shopping of investments, resulting in losses to the Government of India. Round tripping of investments occurs when an investment that originates in one country goes through another country- usually an International Financial Centre such as Mauritius- and then re-enters the first country as foreign investment. Entities would be using "notional residence" in Mauritius to avoid paying taxes in India. It is argued that some of the proposals of the Indian Direct Taxes Code Bill 2013 will affect investors who use Mauritius as a platform for investments into India as well as Indian investors who use Mauritius to invest into the African continent or elsewhere.

\subsection{Residency}

Diamond \& Mirrlees (1971) emphasized that optimal tax theory has held that the residence principle is preferable because it ensures production efficiency but the reach of a country's residence jurisdiction depends on how a taxpayer's residency is established. The Authority for Advance Ruling in India has on several occasions examined the applicability of the Mauritius-India Double Taxation Avoidance Agreement to foreign companies, claiming residence in Mauritius, specifically regarding capital gains tax and dividend tax on income arising from shareholdings in Indian companies. In 2002, in the Azadi Bachao Andolan's case (263 ITR 706), the Supreme Court of India has held that if the Mauritian authority has issued a Tax Residence Certificate, the person is resident of Mauritius. Therefore, as per this decision, in case of countries where it is possible to obtain a Tax Residence Certificate, or otherwise it can be established that a person is a tax resident, Double Taxation Avoidance Agreement benefit will be available (Shanghvi et al., 2013). In October 2004, the Indian Supreme Court upheld the validity of a circular issued by the Indian Central Board of Direct Taxes, which stated that a certificate issued by the Mauritian authorities constituted sufficient evidence of residence in the jurisdiction to allow a firm or investor to take advantage of the provisions of the bilateral Double Taxation Avoidance Agreement between India and Mauritius (Rohatgi, 2007: 390). In October 2006, in an attempt to head off pressure from India to change the countries' Double Taxation Avoidance Agreement, the Mauritian government announced that the tightening up of rules on the issuance of Tax Residence Certificates (Charalambous, 2006). 


\subsection{General Anti Abuse Rules}

The Finance Bill 2013 introduced the General Anti-Abuse Rules with the objective to counter aggressive tax avoidance schemes and proposed an amendment stating that while a tax residency certificate will be necessary, it may not be a sufficient condition to claim treaty relief. The General Anti-Abuse Rules will allow the Indian tax authorities to challenge most structures where investments are channeled through Mauritius or elsewhere if they believe that the structures lack commercial substance has been set up purely for tax reasons. If the General Anti-Abuse Rules is approved in the current format, this will give rise to time consuming and costly litigations, and this may result in investors, prone to risk aversion, to direct their investments to other emerging countries with less fiscal uncertainty (Gowrea and Ramtohul, 2011). Moreover, the term "impermissible avoidance agreement" has been introduced under the provisions of General Anti-Abuse Rules. According to the expert committee constituted by the Indian Prime Minister, General Anti-Abuse Rules can only be implemented in situation where the main purpose is for obtaining tax benefits and not in case where obtaining tax benefits is one of the purpose (Balloo and Sood, 2012). According to the Department of Industrial Policy and Promotion, Foreign Direct Investment equity inflows into India declined 38 percent during April-February 2013 over the previous year, whereby inflows from Mauritius saw a five percent fall Foreign Direct Investment flows from Mauritius were on the wane because of fear that the India-Mauritius Double Taxation Avoidance Agreement would be re-negotiated (Merwin, 2013).

\subsection{Impact of Re-Negotiations on Double Taxation Avoidance Agreement with African Countries}

Corporations and multinationals are now increasingly orienting their outbound investments towards Africa; given that Mauritius has signed Double Taxation Avoidance Agreement with 13 African nations. The impact of the re-negotiation of the Mauritius-India Double Taxation Avoidance Agreement on the network of Double Taxation Avoidance Agreement that Mauritius has with the African continent will be discussed; whereby focus will be in terms of regulatory and legal framework.

\subsection{Renegotiation of Double Taxation Avoidance Agreement by African Countries}

The first African country to review its Double Taxation Avoidance Agreement with Mauritius is South Africa. South Africa's motivation for renegotiating the 1996 tax treaty with Mauritius was revealed by South African Revenue Authority and the National Treasury in 2011. The main reason was perceived abuse of the 1996 tax treaty and resultant erosion of the South African tax base (Finweek, 2013). Strict control measures were introduced in the 1990s by the South African authority, including the relaxation of foreign exchange control, to protect some of the value of the rand. This measure was identified as a major opportunity for Mauritius to attract South African offshore business and was one of the reasons for the signing of the Mauritius-South Africa tax treaty. The South African measures augured well for the Mauritius investment fund industry as South African fund managers were encouraged to set up investment companies for investing in the region (Mauritius Offshore Business Activities Authority, 1997b). The Mauritius-South Africa tax treaty provided South African 
investors with the guarantee of not being taxed twice on the same income, as well as the necessary confidentiality and secrecy regarding their income and assets (Hampton and Abbott, 1999). However, the government of South Africa has, as a result of changes in its domestic laws, revised the Double Taxation Avoidance Agreement in May 2013

\subsection{Obsolete Articles}

Another factor influencing the renegotiation of the Mauritius-India Double Taxation Avoidance Agreement is the fact that the latter is based on the Organisation for Economic Co-operation and Development model, which prevailed in the 1980s, whereby there are articles which have potentially become obsolete, such as the exchange of information article, which has been completed revamped in the 2008 Organisation for Economic Co-operation and Development model (Gowrea, 2011). There have been pressures to review the current Double Taxation Avoidance Agreement to add up articles that were not there at the start, such as mutual assistance for collection of taxes. In fact, the new treaty between Mauritius and South Africa contains the latest Organisation for Economic Co-operation and Development standard for the exchange of taxpayer information as compared to the more limited version of exchange of information where countries could say that they had bank secrecy (Hattingh, 2013). The most significant deviation of the new treaty concerns companies that are tax resident in both Mauritius and South Africa. Such dual residents are subject to double taxation. South Africa follows the place of effective management criterion and under the new tax treaty; the effective management criterion is substituted with an administrative discretion. Barrett (2003) claimed that negotiation of a treaty may be linked to the need at some future date to renegotiate a decision.

\subsection{Limitations on Benefit}

The Indian Government has expressed its desire to insert, in the Double Taxation Avoidance Agreement, provisions on limitation on benefits to be inserted in the tax treaty that are similar to that it has with Singapore, which requires investors coming into India to incur minimum expenditure of US\$200,000 and to have a track record of two years (Basu, 2013). According to Borrego (2006), the purpose of limitation on benefits clauses is to guarantee that the benefits laid down in the convention are only conferred to those who are considered to have a legitimate claim thereto. Artificial structures are not entitled to access the regime of the Double Taxation Avoidance Agreement as a result of the 1 clauses. Consequently, the international tax planning structure adopted must avoid being artificial, given that this is the source of its weaknesses (Spitz, 1991). South Africa and India are two of the largest developing countries with growing pace of development. These countries expect stable long term foreign capital inflows (PricewaterhouseCoopers, 2012) and therefore would no longer require bilateral tax treaties to attract investment and boost economic growth. In addition, tax structures previously considered secure are now being challenged in certain countries and investors are increasingly giving consideration to conducting regular "tax health checks" of their private equity structures in order to minimize potential adverse disruption (Basgeet, 2009). As such, possible uncertainties and litigations concerning the Double Taxation Avoidance Agreement status between Mauritius and any African countries may be 
unfavorably viewed by potential or existing investors, who would be or are using Mauritius as a route for investments into Africa.

\subsection{Loss of Revenue}

Entering a Double Taxation Avoidance Agreement often leads to a loss of tax revenue in developing countries (Easson, 2000). A report by the Africa Progress Panel, led by former UN general secretary Kofi Annan, found that the use of tax havens costs Africa $\$ 38$ billion annually in lost revenue. The Africa Progress Report also revealed that Africa lost close to US\$1 trillion of capital in the past three decades. Hines (2000) found out that a Double Taxation Avoidance Agreement does not only impact on inward Foreign Direct Investment but also on outward Foreign Direct Investment. Although the Double Taxation Avoidance Agreement that Mauritius signed with African countries have been well negotiated so as to be known as a preferred gateway to Africa (Gowrea, 2011), the controversies around the revision to the Mauritius-India Double Taxation Avoidance Agreement can create precedents for African countries, who could follow suit to reduce any loss of revenue. The loss or reduction of tax revenue as a ground for justification has been advanced in several cases on the freedom of establishment in relation to direct taxation (Dahlberg, 2005).

\subsection{Domestic Legislations and Regulations}

The treaty with India, which has underpinned the emergence of Mauritius as the dominant channel for Foreign Direct Investment into India, came under attack from Indian tax authorities as a result of alleged abuses by Indian-resident investors. Mauritius tightened its tax residency requirements and formulated strict anti-money laundering laws. Certain procedures have been established for effective exchange of information, both on request and on a voluntary basis, about suspicious securities dealings (Ball, 2011). Given that private sector development has become a key pillar of growth and development in Africa, institutions have invested growing amounts of money to support both the reform of regulations aimed to improve the business climate and strategic private sector operations expected to catalyze further private sector development through linkages and demonstration effects (Marco et al., 2011). The World Bank Doing Business Report (2012) indicated that a record $78 \%$ of African economies pursued regulatory reforms. Over the past six years, the average had stood at $56 \%$. According to the 2011 Ernst and Young "Africa Attractiveness Survey", annual investment from emerging partners grew on average 13\% annually over the past decade. Although the short term investment outlook for Africa remains cautiously optimistic, in line with the sustained Foreign Direct Investment flows, it should be recognized that emerging African countries are still in the early stage of attracting Foreign Direct Investment and may not have appropriate mechanism to monitor investments yet. However, given the positive outlook based on the sustained strong economic growth in Africa and the improvement of the business climate and competitiveness, the situation may change (Marco et al., 2011). An African country will be able to apply domestic anti-abuse provisions in addition to the provision in a tax treaty. This is supported by the Para 9.6 of the Organisation for Economic Co-operation and Development commentary:

"9.6 The potential application of general anti-abuse provision does not mean that there is no 
need for the inclusion, in tax conventions, of specific provision aimed at preventing particular forms of tax avoidance. Where specific avoidance techniques have been identified or where the use of such techniques is especially problematic, it will often be useful to add to the Convention provisions that focus directly on the relevant avoidance strategy..."

While the Organisation for Economic Co-operation and Development did not attempt to define what is an abuse of the provisions of a tax treaty, the following general guidance in Para 9.5 of the Commentary of Art. 1:

"9.5 A guiding principle is that the benefits of a double taxation convention should not be available where a main purpose for entering into certain transactions or arrangements was to secure a more favourable tax position and obtaining that more favourable treatment in these circumstances would be contrary to the object and purpose of the relevant provisions."

The Double Taxation Avoidance Agreement can be challenged if tax authorities in African countries attempt to disallow tax exemption granted by Mauritius to investors, using a Global Business Company 1 as a conduit for African investment, by formulating provisions in their domestic laws, which will target even bona fide legitimate transactions. Asiedu (2003) used panel data on 22 African countries for the period 1984-2000 to examine empirically the impact of several variables including natural resource endowment, macroeconomic instability, Foreign Direct Investment regulatory framework, corruption, effectiveness of the legal system and political instability on Foreign Direct Investment flows. The paper debunks the notion that Foreign Direct Investment in Africa is solely driven by natural resource availability and concludes that natural resource endowment, large markets, good infrastructure and an efficient legal framework promote Foreign Direct Investment, while macroeconomic instability, corruption, political instability and investment restrictions deter investment flows. In the short and medium term, government can increase their Foreign Direct Investment by streamlining their investment regulation framework, implementing policies that promote macroeconomic stability and improving infrastructure. An understanding of the domestic limitation on benefits provisions applicable to the tax treaties entered into by some African jurisdictions is also essential if transaction pitfalls are to be avoided (Steenkamp and Hales, 2013).

\subsection{Permanent Establishment}

According to Reimer, Schmid and Urban (2013), permanent establishments are a key facet of international taxation. They constitute the crucial threshold for the assignment of taxing rights to a jurisdiction in all cases of enterprises operating in more than one country. They further stated that the issue of whether there is a Permanent Establishment and how much profit should be allocated to it, is an increasingly important factor in tax planning, tax compliance and related tax risk management. Article 7 of the Organisation for Economic Co-operation and Development Model Tax Convention on Income and Capital addressing the taxability of business profits, stipulates that the profits of an enterprise of a contracting state are to be taxed only in that state, unless the enterprise carries on business in the other contracting state through a permanent establishment situated there. If a permanent establishment has been created, the profit may be taxed in the other state only to the extent 
that is attributable to that establishment. Article 5 defines permanent establishment as a fixed place of business through which the business of the enterprise is wholly or partly carried out. Controversy over the Mauritius-India Double Taxation Avoidance Agreement has grown in India as there are no strict legal definitions for the terms "management from Mauritius" or "permanent establishment" (Bloodgood, 2007). In the Azadi Bachao Andolan's case (263 ITR 706), the appellant argued that the Global Business Company 1 are mostly 'shell companies' incorporated in Mauritius and operating through Mauritius, whose main purpose was investment of funds in India. It was alleged that these companies were controlled and managed from countries other than India or Mauritius and as such they were not "residents" of Mauritius so as to derive the benefits of the Double Taxation Avoidance Agreement. The revised proposals concerning the interpretation and application of Article 5 of the Organisation for Economic Co-operation and Development Model tax Convention issued in 2012 states that the terms listed 'a place of management', 'a branch', 'an office' must be interpreted in such a way that such places of business constitute permanent establishments only if they meet requirements of Paragraph 1 of Article 5. Following renegotiations of the Double Taxation Avoidance Agreement, the Government of South Africa has recently changed its administrative rules to stipulate that non-resident companies need to register with the South African Revenue Service as a taxpayer if they carry on a trade through a permanent establishment in South Africa or they derive a capital gain from a source within South Africa.

\subsection{Latest Developments about the Double Taxation Agreement Terms}

As per Le Mauricien (2015), one of the leading newspapers in Mauritius:

- The Global Business Sector (GBS) has been in the news lately following the announcement on 30 June 2015 by the Ministry of Finance that the renegotiation of the terms of the Double Tax Avoidance Treaty (DTAT) with India was finally over and this was followed by public concerns raised on 6 July 2015 by experts in the domain, notably Messrs Dan Maraye \& Rama Sithanen, about the concessions made with respect to some of the litigious clauses of the DTAT, which were likely to derail the GBS for good.

- The pressure groups in India argue that many investors are in fact Indians who set up companies in Mauritius and invest in their own country from Mauritius - a process known as 'round-tripping' - with a view to avoid tax in India. This issue has been taken into account by Mauritian authorities which reinforced the local rules to facilitate identification and prevention of investments funds sourced from India. Additionally the Indian tax authority seems to nurture the belief, echoed in certain sections of the Indian press, that the tax revenue would be higher if investors did not channel investments through Mauritius. A possible fallacy in this line of thinking would be in the assumption that investors are perfectly indifferent to tax rates.

- On the basis of media reports, the Joint Working Group seems to have agreed to add a clause to the Double Tax Avoidance Treaty on 'limitation of benefits' (LoB) under which global business companies (GBCs) set up by international investors in Mauritius would have to incur annual administrative expenses of at least Rs1.5 million in Mauritius for at least two consecutive years to be eligible for the DTAT provisions. Though this requirement would 
reinforce the 'substance' of GBCs, it may have the unwelcome effect of being too onerous for smaller foreign investors holding few investments in India and drive them out, along with the Mauritian management companies servicing them.

- Clause 13 of the Double Tax Avoidance Treaty is considered one of the litigious parts and the Mauritian counterparts in the negotiation process had over the years defended it from removal or modification. The Clause 13 provides that the gains made by sales of assets such as shares held in Indian companies by Mauritian GBCs are taxed in Mauritius and not India. The capital gains tax rate in Mauritius is in effect zero. Altering Clause 13 - for instance by providing for capital gains to be taxed in India - would therefore drive investors away from Mauritius and thereby hurt the GBS beyond repair.

- Management companies which administer GBCs would take a severe hit, along with international banks which channel investors' funds and audit firms which conduct the audit of the financial statements of GBCs. Employment in these service providing firms would certainly be jittery and fresh graduates will see their employment opportunities severely hampered. A growing number of GBCs also have local offices and employees who might get the axe. Even peripheral service providers, like taxi drivers who service employees in this sector, would be hit. The ripple effect in the whole economy would be unavoidable.

- Mrs Sushma Swaraj, the Indian External Affairs Minister, gave the assurance that the interest of Mauritius would be secured under the terms of a renegotiated Double Tax Avoidance Treaty during her visit to Mauritius in November 2014. Mr Narendra Modi, the Indian PM, also stated during his two-day visit in March 2015 that "nothing will be done to harm this critical sector" of Mauritius. The Mauritian Finance Minister stated on 30 June 2015 the negotiations had culminated in a positive 'denouement', thanks in large part to the above mentioned assurance given by Mr Modi.

All the above made it important to research and shed light in this blurred area.

\section{Methodology}

The approach to empirical research adopted for this study was one of a qualitative, semi-structured questionnaire methodology. By employing qualitative mode of enquiry, it was attempted to investigate how the different stakeholders within the financial services sector in Mauritius assess the impact of the re-negotiation of the Mauritius-India Double Taxation Avoidance Agreement on the Double Taxation Avoidance Agreement between Mauritius and the African continent.

\subsection{Population and Sampling}

The portion of target population to which the researcher has reasonable access is known as the accessible population (Simelane, 1998:24). The target population for this research was directors and/or senior officers of: management companies, financial regulatory bodies, tax firms and law firms in Mauritius. The sampling procedure are based entirely on the judgement of the researcher in that the sample consists of elements, which contain the most characteristics representative or typical attributes of the population (Strydom \& Devos 
1998:198). Hoberg (1999:61) states that a great concern for researcher remains the sample size. This research was based on one director/senior officer from each 92 management companies, 42 directors/senior officers from the regulatory bodies, 11 directors/senior officers from tax firms and 5 directors/senior officers from law firms; all in order to obtain a final sample of 150 for the sake of quantitative research using semi-structured questionnaires. This method of stratified random sampling ensured representativeness within the sample, thereby ensuring that generalization can be assured at the end of the research as per outcomes obtained through the conduct of the research. Moreover, there were more management companies because in Mauritius as per News on Sunday (2013) we will face a substantial drop in activity in the global business sector towards India, which will only compound the fragility of the sector these days, with the various initiatives having taken place internationally. Hence, making imperative to include more management companies in the research.

\subsection{The Research Design}

This exploratory research was conducted by doing a pilot study and a search of the literature applicable to the objective of the study. Subsequently, a descriptive research was carried out by interviewing the target population through a semi-structured questionnaire and unstructured interview and analysing the data gathered to examine the relationship between variables. For the purpose of this study, a positivist research strategy will be adopted through semi-structured questionnaires in order to obtain unbiased answers and for more valid outcomes. Questionnaires are easy to administer, quick to fill and can be answered by all respondents simultaneously (Hopkins 1993). The questionnaire consisted of close-format, rating scale and a few open ended questions so as to elicit more profound responses. All questionnaires need to undergo a pilot test before being used for data collection (Saunders et al; 2009:394). The complexity of the questions is an important consideration because the research study could suffer from the respondents' misunderstanding of the questions. A pre-testing of the questionnaire was done with ten individuals and necessary corrections were made to improve it accordingly.

\subsection{Data Analysis}

Data collected in the questionnaires was coded, captured in Microsoft Office Excel 2010 and in Statistical Package for the Social Sciences (SPSS) version 17.

\section{Results and Discussions}

A total of 92 responses were received from the targeted 150 potential respondents, and this $61.33 \%$ response rate can be explained by the fact that this industry is a fast moving one in which work schedules are hectic.

\subsection{Development of Mauritius Global Business Centre}

Respondents were asked whether they agree with the statement that "Mauritius has focused the development of its global business centre on the use of its growing network of Double Taxation Avoidance Agreement" and 89.1\% agreed while 10.9\% disagreed. As mentioned in 
the literature review, since the creation of the global business sector in 1992, the Government has concluded 37 Double Taxation Avoidance Agreement and is party to a series of treaties under negotiation. This reinforces the seriousness of Mauritius as a tax efficient offshore jurisdiction for structuring investment abroad. Moreover, according to figures from the Financial Services Commission, the number of Global Business Company 1 has increased considerably over the past decade. There are several possible explanations for the $10.9 \%$ of the respondents who did not agree with the statement; essentially other factors which could have also helped to the contribution of the success of the global business sector, such as the tax exempt Global Business Company holding category two licence, bold reforms adopted in 2006 whereby companies can be incorporated within three working days, the legal and regulatory framework, the political and social stability, amongst others.

\subsection{Importance of Mauritius-India Double Taxation Avoidance Agreement}

This study has been set out with the objective of assessing the importance of the Mauritius-India Double Taxation Avoidance Agreement to both countries. $63.04 \%$ respondents strongly agreed while $36.96 \%$ agreed that the Double Taxation Avoidance Agreement has increased the level of cross border investment between the two countries. Prior studies have noted the importance of Double Taxation Avoidance Agreement on the level of cross-border investments. As mentioned in the literature review, Hines (2000) and Millimet and Kumas (2008) stated that Double Taxation Avoidance Agreement has an impact on inward and outward Foreign Direct Investment. A strong relationship between Double Taxation Avoidance Agreement and inward Foreign Direct Investment has been reported in the literature. This study further confirms that Double Taxation Avoidance Agreement is associated positively with the level of inward Foreign Direct Investment since 51.09\% strongly agreed and $48.91 \%$ agreed to the statement that the Double Taxation Avoidance Agreement has significantly helped to increase the level of inward Foreign Direct Investment to India. This result may be explained by the fact that India has received a maximum of Foreign Direct Investment from Mauritius, which is why the latter is the largest source of Foreign Direct Investment as confirmed by statistical figures provided by the Department of Industrial Policy and Promotion of India. Another important finding was that of the relationship between Double Taxation Avoidance Agreement and economic growth. 32.61\% strongly agreed and $67.39 \%$ agreed to the statement that the Double Taxation Avoidance Agreement between Mauritius and India has benefited both countries in achieving higher economic growth. Very little was found in the literature on the direct relationship between Double Taxation Avoidance Agreement and economic growth although Borensztein et al (1998), Te Velde and Morissey (2002) and Gani (1999) found that there is a positive relationship between Foreign Direct Investment and economic development. Given that it has been shown that there is a positive relationship between Double Taxation Avoidance Agreement and Foreign Direct Investment, it is possible to hypothesise that the level of Foreign Direct Investment as a result of the Double Taxation Avoidance Agreement is positively linked to the level of economic growth. This is an important issue for future research. If we now turn to whether the cultural link between Mauritius and India has contributed in promoting the Double Taxation Avoidance Agreement, 34.78\% strongly agreed 
and 57.61 agreed to the statement while $7.61 \%$ were uncertain about the relationship. These data must be interpreted with caution because the cultural link had an implication on the terms of the Double Taxation Avoidance Agreement between the two countries, given that India looked upon Mauritius with a fraternal eye- the majority of the Island's population was of Indian origin, and the cultural link may have helped to maintain these terms. However, further work is required to establish whether the cultural closeness of nearly half a century has directly contributed. Very few were found in the literature on the relationship between the Investment Promotion and Protection Agreement between Mauritius and India and the success of the Double Taxation Avoidance Agreement between the two countries. It was somewhat surprising that $15.22 \%$ strongly agreed and $63.04 \%$ agreed to the statement while $21.74 \%$ were not certain on the impact of the Investment Promotion and Protection Agreement on the success of the Double Taxation Avoidance Agreement. The possible interference of the Investment Promotion and Protection Agreement therefore cannot be ruled out. In fact, as stated in the literature review, both Governments have recognized that the Investment Promotion and Protection Agreement will lead to greater stimulation to the development of business initiatives and allow country risks. $23.91 \%$ strongly agreed and $67.39 \%$ agreed to the statement that Mauritius's regional knowledge and agreements have assisted in the success of the Double Taxation Avoidance Agreement while $8.70 \%$ were uncertain. There are several possible explanations for this. Mauritius provides investors who want a diverse portfolio with a single base of operations instead of multiple bilateral investments; hence, investors wishing to invest into India and other countries within the region would use the Mauritius platform and therefore, also the Double Taxation Avoidance Agreement between Mauritius and India. Moreover, outward Foreign Direct Investment from India for investors wishing to invest into countries, with which Mauritius has regional knowledge and agreements, will also use the Mauritius-India Double Taxation Avoidance Agreement. With regard to the extent to which international recognition of Mauritius as a financial centre has contributed to the success of the Mauritius-India Double Taxation Avoidance Agreement, $21.74 \%$ strongly agreed, $57.61 \%$ agreed and $20.65 \%$ were not certain. The overall response to this statement was very positive. It seems possible that these results are due to the very attractive international ranking by World Bank Doing Business, Ease of Doing Business, Ease of starting a Business, Protecting investors, Trading Across Borders, Mo Ibrahim Index of African Governance, Global Competitiveness Index and The Wall Street Journal \& The Heritage Foundation Index of Economic Freedom. Global investors' confidence and trust in the jurisdiction might have increased, thus allowing for more use of the Mauritian platform by the international business community. It is interesting to note that, from the above seven cases, the Mauritius-India Double Taxation Avoidance Agreement has been beneficial to both countries in terms of cross-border investments, level of inward Foreign Direct Investment and economic growth. There is also evidence that Investment Promotion and Protection Agreement, regional knowledge and agreements as well as international recognition have contributed to the success of the Mauritius-India Double Taxation Avoidance Agreement. 
4.3 Interest for Re-Negotiation of Mauritius-India Double Taxation Avoidance Agreement

Another question of this research was to determine whether or not players in the industry thought that it would be of interest for re-negotiation of the Mauritius-India Double Taxation Avoidance Agreement. Surprisingly, although $69.57 \%$ believed it is necessary, $30.43 \%$ did not. It is however important to bear in mind the possible bias in the responses of those who think that the re-negotiation is not necessary. Further analysis of those who consider it is necessary for re-negotiation of the treaty was carried out through opened-end questions. The majority of the respondents felt that it is necessary for the following reasons:

1. To avoid treaty shopping

2. Abuses of the treaty by Indian residents through round-tripping

3. To identify loopholes in the treaty

4. To adjust to new economic conditions

5. To review obsolete clauses in the treaty, such as the exchange of information article

6. To set established rules about the definition of 'substance requirement' and 'permanent establishment'

7. To show cooperation in finding a mutually acceptable treaty that can benefit both member countries

\subsection{Reasons for Re-Negotiation of Mauritius-India Double Taxation Avoidance Agreement}

The present study was also designed to determine the reasons leading to the re-negotiation of the Mauritius-India Double Taxation Avoidance Agreement. A list of possible reasons as set forth by authors and stakeholders in the industry was provided and respondents were asked to comment on the level of importance as regards the re-negotiation. The majority, $61.96 \%$, of the respondents felt that treaty shopping has led to the re-negotiation of the Double Taxation Avoidance Agreement between Mauritius and India. This finding corroborates the ideas of Blonigen and Davies (2004), who suggested that one of the functions of a Double Taxation Avoidance Agreement is to restrict treaty shopping. Mauritius has indeed been severely criticized for being a financial jurisdiction for treaty shopping. It is nonetheless important to highlight that although the remaining respondents considered that treaty shopping is not that important, by answering the question, it is assumed that they believed that it however contributed to the re-negotiation of the Mauritius-India Double Taxation Avoidance Agreement. The findings support the idea that the loss of revenue is another major reason for the re-negotiation of the Double Taxation Avoidance Agreement. A high response of 59.78\% believed that it is a very important, $11.96 \%$ that it is important and $8.70 \%$ moderately important. Indeed, criticisms and court cases suggested that this would highly affect the Double Taxation Avoidance Agreement between the two countries. Almost around three-quarter of the participants $(77.17 \%)$ felt that round tripping and abuse by Indians are important or very important in contributing to the re-negotiation of the Double Taxation Avoidance Agreement. The present findings therefore seem to be consistent with criticisms from stakeholders for encouraging round-tripping, thereby resulting in losses to the Government of India. Mauritius's control on the Indian's stock market has been presented as one of the reasons for re-negotiation of the Double Taxation Avoidance Agreement, to which 
only $8.70 \%$ believed is important while $60.87 \%$ is moderately important and $30.44 \%$ felt is of little or least important. Contrary to expectation, this study did not find a significant implication of Mauritian entities being listed on the Indian's stock market as being a major reason for the re-negotiation of the treaty. Also, the majority of respondents $(72.82 \%)$ believed that the controversy around the residency status or permanent establishment is a key factor for the re-negotiation of the treaty. $14.13 \%$ felt that it has moderately contributed while $13.04 \%$ that it is of little importance. The finding accords with the literature review, which stated that the controversy over the Mauritius-India Double Taxation Avoidance Agreement has grown in India because there are no strict legal definitions for the terms "management from Mauritius" or "permanent establishment" (Bloodgood, 2007). Turning now to another factor implicit to the Double Taxation Avoidance Agreement is the argument that there are articles that are now obsolete and need to be reviewed. A striking result to emerge from the data is that only $21.74 \%$ thought that this would be an important reason for the re-negotiation while $46.74 \%$ thought it is moderately important and $31.52 \%$ that it is of little importance. This finding has been unable to demonstrate that the outdated articles in the Double Taxation Avoidance Agreement could be a major reason for the re-negotiation. However, while interpreting the data, it is important to indicate that all respondents agreed that it could have to some extent influenced the re-negotiation. Moreover, only $20.65 \%$ considered that insufficient exchange of information from Mauritius could have been an important factor leading to the re-negotiation of the Double Taxation Avoidance Agreement. 21.74\% thought that this reason is moderately important. Surprisingly, $50 \%$ of the respondents believed that insufficient exchange of information is of little importance for requiring the re-negotiation of the treaty and $7.61 \%$ felt it is of least importance. It seems possible that these results are due to the fact that both countries have signed a Memorandum of Understanding for effective exchange of information in the detection of fraudulent market practices and have also agreed on a new Tax Information Exchange Agreement. 55.44\% felt that money laundering control in India could be an important or very important factor leading to the negotiation of the Double Taxation Avoidance Agreement. $23.91 \%$ believed that it is a moderately important reason while $20.65 \%$ attributed it with little importance. Of the 92 individuals who completed the questionnaire, over half indicated that money laundering control could be a major reason. The figures accord with earlier discussion on round-tripping of funds and abuse by Indians. In fact, the Income Tax Department through the Central Board of Direct Taxes and the enactment of the Prevention of Money Laundering Act 2002 as well as the Joint Working Group comprising members of both governments indicate that there has been increasing implementing money laundering control. Nevertheless, it should be noted that many respondents believed that this is moderately important or of little importance, most probably because Mauritius follows all international standards on information exchange and anti-money laundering and counter financing of terrorism.

Furthermore, $58.69 \%$ of the respondents believed that improved regulatory framework for attracting investment in India could be an important or very important reason for the re-negotiation of the treaty. $32.61 \%$ felt it is only moderately important while $8.70 \%$ that it is of little importance. This also accords with the earlier observation on anti-money laundering regulations in India; however, more research need to be undertaken to understand clearly to 
what extent the improved regulatory framework in India would affect the terms of the treaty. Surprisingly, only a small number of respondents $(2.17 \%)$ indicated that a wrongly negotiated Double Taxation Avoidance Agreement is an important factor, resulting in the need by the Indian Government to re-negotiate the treaty. $25 \%$ believed this is a moderately important factor, $52.17 \%$ that it is of little importance and $20.65 \%$ that it is least important. Again, the results should be interpreted with caution as although the 'wrongly negotiated Double Taxation Avoidance Agreement' is being identified as a possible reason for the re-negotiation, it cannot be extrapolated to the extent to which the Double Taxation Avoidance Agreement has been wrongly negotiated. The majority of the respondents $(61.95 \%)$ thought that too much Foreign Direct Investment from Mauritius into the Indian economy could be an important or a very important reason for the re-negotiation of the Double Taxation Avoidance Agreement. $31.52 \%$ of the participants felt it is moderately important while a minority of participants $(6.52 \%)$ considered that this is of little importance. This rather contradictory result, compared results pertaining to the relationship between Double Taxation Avoidance Agreement (and by implication the level of inward Foreign Direct Investment) and economic growth, may be explained by the fact that the Indian authorities seem to have become doubtful about the purpose of using the Mauritius platform to access the Double Taxation Avoidance Agreement and subsequently the loss of revenue. Another reason listed is the need for diversification of India's source of Foreign Direct Investment to avoid an over dependence on Mauritius. The views are quite diverse; $6.52 \%$ thought that it is very important, $9.78 \%$ that it is important and $30.43 \%$ that it is moderately important. However, the majority of respondents $(53.26 \%)$ considered that this factor is of little or least importance. This is possibly because the Double Taxation Avoidance Agreement has been beneficial to both countries and a revision will have some negative impacts on the level of Foreign Direct Investment into India, which shows that both countries are probably dependent on the treaty.

\subsection{Accumulation of Optimum Level of Foreign Direct Investment}

One unanticipated finding was when respondents were asked whether they think that India has asked for the revision of the Double Taxation Avoidance Agreement after accumulating the optimum level of Foreign Direct Investment. A majority of $60.87 \%$ did not consider it as the reason for the revision while only $39.13 \%$ believed it is the case.

\subsection{Central Management}

Very little was found in the literature on the question of 'central management'. $64.13 \%$ of those who responded indicated that the concept of 'central management' has to be changed to take into consideration the new recommendations of the Organisation for Economic Cooperation and Development. However, $35.87 \%$ do not think that when re-negotiating the Mauritius-India Double Taxation Avoidance Agreement, the 'central management' requirement should be changed to conform to the new recommendations of the Organisation for Economic Co-operation and Development. This can possibly be explained by the facts that the Double Taxation Avoidance Agreement was initially negotiated and concluded according to the Organisation for Economic Co-operation and Development model and that the Mauritian domestic legislations account for the pre-requisites for central management. 


\subsection{Provisions of General Anti-Abuse Rules/Limitation on Benefits}

On the question of General Anti-Abuse Rules and limitation on benefits, the results are consistent with those of other studies and suggest that a majority of $84.78 \%$ felt that the implementation of these provisions will lead to a reduction of Foreign Direct Investment inflows through Mauritius into India. There are several possible explanations for this result:

- Global Business Licence 1 companies domiciled in Mauritius may have to go through substantial procedures to prove that they have created the structure for genuine business purposes and not just for avoidance of tax;

- General Anti-Abuse Rules could give powers to the tax department to deny Double Taxation Avoidance Agreement benefits to foreign funds based in Mauritius;

- Investments into Indian stock markets might slow after the introduction of General Anti-Abuse Rules. According to data from market regulators, if tax would be imposed on the registered financial firm buying the security on behalf of the client, the brokerage may then pass on the taxes to the end investors;

- Investing in India through the Singapore route can gain prominence considering that it is a developed economy and many foreign investors may already have considerable operations there.

Nonetheless, $15.22 \%$ of respondent believed that the implementation of the provision of the General Anti-Abuse Rules/Limitation on Benefits will not affect the Foreign Direct Investment inflows through Mauritius to India. These data must be interpreted with caution, possibly because the knowledge and exposure of respondents to the implications of General Anti-Abuse Rules/Limitation on Benefits is rather unknown. More research on this topic needs to be undertaken.

\subsection{Impact of Re-Negotiation of Double Taxation Avoidance Agreement with African Continent}

Traditionally, the re-negotiation of the Mauritius-India Double Taxation Avoidance Agreement has been assessed by measuring its impact on both member countries. The present study was designed to determine the impact of the re-negotiation of the Mauritius-India Double Taxation Avoidance Agreement on those that Mauritius has with the African continent. The results of this study indicate that $71.74 \%$ of respondents thought that there will be an impact on the Double Taxation Avoidance Agreement between Mauritius and the African countries while $28.26 \%$ believed that there will be no impact. These findings will doubtlessly be much scrutinised, but there are some immediate reasons provided by the respondents who think that the Double Taxation Avoidance Agreement with the African continent will be affected:

- In light of changing legislations, African countries will ultimately look at re-negotiating their Double Taxation Avoidance Agreement;

- A precedent will be established and governments of African countries are bound to follow;

- Mauritius will be an unstable platform to invest in African countries; 
- African countries will not want to be in the same position as India today;

- African states will take the opportunity to optimise the conditions under which their own treaties with Mauritius operate;

- Management companies will focus on African countries and move out of India, which will create an overflow on the African market.

\subsection{Review of Double Taxation Avoidance Agreement by Other African Countries}

A significant $92.39 \%$ of the participants expressed their belief that after South Africa, other African countries will want to review their Double Taxation Avoidance Agreement with Mauritius while only $7.61 \%$ thought that other African countries will not do the same. Some of the reasons put forward by the respondents, who believed that other African countries will follow, include the following:

- African countries will want to avoid misuse of treaty;

- For exchange of information between the two countries;

- The Mauritius-India Double Taxation Avoidance Agreement re-negotiation will set a precedent;

- It will be an opportunity for African countries to re-negotiate the Double Taxation Avoidance Agreement more to their advantage;

- African countries will implement regulatory reforms to improve business environment;

- To benefit from new treaty provisions and protect local/domestic markets;

- To review obsolete clauses in the Double Taxation Avoidance Agreement and limit the effect of treaty shopping;

- Because Mauritius has no other option than to accept to re-negotiate in order to show transparency.

This finding has important implications for this study as it will enable to determine whether after India and the first African country, that is South Africa, our Double Taxation Avoidance Agreement with other African countries will be re-negotiated. The above reasons advanced seem to be consistent with other findings pertaining to the re-negotiation of Double Taxation Avoidance Agreement.

\subsection{Assessment of Impact of Re-Negotiation on Double Taxation Avoidance Agreement} between Mauritius and Africa Countries

This study has been set out with the aim of assessing the impact of the re-negotiation of the Double Taxation Avoidance Agreement between Mauritius and India on the Double Taxation Avoidance Agreement that Mauritius has with the African countries.

Participants were asked to respond to the extent to which they agreed or disagreed with statements, which have been identified as possible implications of the re-negotiation of the Mauritius-India Double Taxation Avoidance Agreement. The overall response was very positive to the question of whether African countries that signed Double Taxation Avoidance Agreement some while ago, would want to revise the terms of their Double Taxation Avoidance Agreement to take into consideration new recommendations from the 
Organisation for Economic Co-operation and Development. 33.70\% strongly agreed and $57.61 \%$ agreed to the statement. $8.70 \%$ were not certain. The results were consistent with other researches, which found that changes in the international standards will mostly lead to the need to renegotiate Double Taxation Avoidance Agreement between Mauritius and African countries, although they have been drafted properly at the time of execution. Participants were asked to comment on the extent to which the implementation of the General Anti-Abuse Rules/limitation on benefits by India will influence other African countries having Double Taxation Avoidance Agreement with Mauritius to include the same provisions in their Double Taxation Avoidance Agreement. As mentioned in the literature review, the Indian Government has expressed its desire to include, in the Double Taxation Avoidance Agreement, provisions on limitation on benefits in addition to the General Anti-Abuse Rules that has been proposed in the Finance Bill 2013. 28.26\% strongly agreed and 47.83\% agreed to the statement that African countries will most likely be influenced to do the same. What is interesting in this data is that $23.91 \%$ were not certain and this result could be explained by the fact that most of the African countries were developing countries and required more foreign direct investments for their economic growth. It is therefore assumed that participants responded by taking into account the immediate effect on Double Taxation Avoidance Agreement with African countries. On the question of whether African countries will adopt appropriate mechanism to monitor inward and outward investments, the findings indicated that $91.3 \%$ strongly agreed or agreed to this statement. This finding is in agreement with the ideas of Marco et al. (2011), who stated that institutions in Africa have invested growing amounts of money to support both the reform of regulations aimed to improve the business climate and strategic private sector operations. $8.70 \%$ of the respondents were not certain of this implication on the Double Taxation Avoidance Agreement between Mauritius and African countries. This can be explained by the fact that emerging African countries are still in the early stage of attracting Foreign Direct Investment and may not have appropriate mechanism to monitor investments yet. Participants were further asked to state to what extent they agreed or disagreed that any positive changes in the domestic law of the African countries will have a negative effect on investments flowing though Mauritius and by implication on the Double Taxation Avoidance Agreement with African countries. $71.74 \%$ of the respondents stated that they agreed or strongly agreed with the statement. These findings seemed to be consistent with other research which found that if tax authorities in African countries attempt to disallow tax exemption granted by Mauritius to investors by formulating provisions in their domestic laws, which will target even bona fide legitimate transactions; this will have a negative impact on the Double Taxation Avoidance Agreement. Moreover, it has been found that domestic tax legislation may sometimes override tax treaty provisions. Moreover, $14.48 \%$ were uncertain of and $9.38 \%$ disagreed to this implication. It is difficult to explain by this result but, it might be related to the fact that curbing corruption, developing a more efficient legal framework and reducing political instability is essential before implementing domestic limitation on benefits or tax legislations. Interestingly, when asked whether investors will reconsider investing through Mauritius given the instability and litigations regarding the status of the Double Taxation Avoidance Agreement, only 29.34\% agreed and strongly agreed. As mentioned in the literature review, investors are increasingly 
conducting regular "tax health checks" of their structures in order to minimize potential adverse disruption. However, $39.13 \%$ of the respondents were uncertain and $31.52 \%$ disagreed. A possible explanation for these results may be the fact that Mauritius is internationally recognized as a well-managed centre that maintain high levels of supervision and best practices and is classified in the Organisation for Economic Co-operation and Development white list, which subsequently reduces the impact of any litigations or instability surrounding the Double Taxation Avoidance Agreement. Another important finding was concerning the level of substances of entities incorporated in Mauritius to have access to the network of Double Taxation Avoidance Agreement with the African continent. $44.57 \%$ of the respondents strongly agreed and $55.43 \%$ agreed that the re-negotiation of the Mauritius-India Double Taxation Avoidance Agreement will result in investors establishing entities with appropriate level of substance in Mauritius so as not to jeopardise their residency status. In fact, criticisms from India and South Africa, who expressed their desire to re-negotiate their treaties, have essentially been on the "residency" status of companies established to take advantage of Double Taxation Avoidance Agreement.

\subsection{Domestic Anti-Abuse Rules}

$85.87 \%$ of the participants thought that domestic anti-abuse rules in African countries will prevent tax avoidance and reduce revenue losses while $14.13 \%$ did not think so. This showed strong evidence that domestic anti-abuse regulations will also have an impact on the Double Taxation Avoidance Agreement that African countries have with Mauritius. Some African countries already made provisions in their domestic legislations for the applicability of such regulations. A further study with more focus on domestic anti-abuse rules is therefore suggested.

\subsection{Permanent Establishment}

With regard to the concept of 'permanent establishment', which has been at the center of considerable controversy, $86.96 \%$ of respondents thought that the revision of the concept and definition would provide home countries more comfort on the residency status while only $13.04 \%$ replied negatively.

\subsection{Measures to Limit Impact of Re-Negotiation}

To the last question of the questionnaire, which was an open-ended question, participants were asked to suggest the measures that should be taken to limit the impact of the re-negotiation of the Mauritius-India Double Taxation Avoidance Agreement on the Double Taxation Avoidance Agreement that Mauritius has with the African countries. The overall response to this question was very poor. Some participants considered that the proactive measures that must be adopted will depend largely on the changes that are being made or will possibly be required to the Double Taxation Avoidance Agreement. Most of the respondents expressed the belief that re-negotiations of Double Taxation Avoidance Agreement should be done very transparently, whereby the right balance of stakeholders discussed to arrive at an agreement which is beneficial to both member countries. It was further suggested that the Mauritian authorities or regulators should ensure that any negative publicity surrounding a 
renegotiation is avoided. According to some, Mauritius has to undertake extensive informational and promotional campaign to maintain itself as a jurisdiction of high repute but, how to do it is a potential research area. Other responses to this question included measures to allow more exchanges of information between member countries and the implementation of more strict legislations and regulations to avoid round-tripping, money laundering and abuses. The element of central management and control has been particularly mentioned. Respondents revealed that resident entities which operate outside Mauritius and have access to Double Taxation Avoidance Agreement should create substance in Mauritius. It was also proposed that there should be a limit for the number of directorships so that a director can reasonably undertake his duties. In addition to the above, respondents also stated that investors should be encouraged to set up 'real offices' in Mauritius. It is therefore important to improve the image of Mauritius as a jurisdiction of substance. However, one individual stated that nothing much can be done although requiring more substance may negate the negative impact of the re-negotiations to some extent.

\section{Conclusion and Recommendation}

The overriding purpose of this study was to determine the implications of the re-negotiation of the Mauritius-India Double Taxation Avoidance Agreement on the network of Double Taxation Avoidance Agreement that Mauritius has with the African continent. To accomplish that goal, it became necessary to reach some prerequisite goals, such as investigating on the relevance of the Mauritius-India Double Taxation Avoidance Agreement to both member countries and evaluating the reasons for the re-negotiation of the Mauritius-India Double Taxation Avoidance Agreement.

Returning to the question posed at the beginning of this study, it is now possible to state that the re-negotiation of the Mauritius-India Double Taxation Avoidance Agreement might have an impact on the Double Taxation Avoidance Agreement that Mauritius has with African countries.

The relevance of the Mauritius-India Double Taxation Avoidance Agreement to both member countries is clearly supported by current findings, which illustrated that it has contributed to the cross-border investments as well as increased the level of inward Foreign Direct Investment and economic growth in both countries. It has also been found that cultural link, Investment Promotion and Protection Agreement, regional knowledge and agreements as well as international recognition are factors which could have assisted in the success of the Indo-Mauritius treaty. The study has also shown that treaty shopping, loss of revenue, round tripping or abuse by Indians, controversy around the residency status or the meaning of permanent establishment, money laundering control in India, improved regulatory framework for attracting investments directly and too much Foreign Direct Investment from Mauritius into the Indian economy are the main reasons for the discussions on the re-negotiations of the Double Taxation Avoidance Agreement between Mauritius and India. Factors such as Mauritius' control on the Indian's stock market, obsolete articles in the Double Taxation Avoidance Agreement, insufficient exchange of information from Mauritius, wrongly negotiated Double Taxation Avoidance Agreement and the need for diversification of India's 
source of Foreign Direct Investment were poorly rated by participants. To achieve another set of objective for this study, it was necessary to determine whether factors which resulted into the re-negotiation of the Mauritius-India Double Taxation Avoidance Agreement would also cause instability to and challenge the Double Taxation Avoidance Agreement between Mauritius and African countries. It was considered by all respondents in the context of the impact on the Double Taxation Avoidance Agreement with African countries that implementations of new Organisation for Economic Co-operation and Development recommendations, General Anti-Abuse Rules/limitation on benefits measures and appropriate monitoring mechanism were ranked high. Although the sample populations were relatively small, responses indicated that one of the encouraging impacts of the re-negotiation of the treaty between Mauritius and India is that investors will establish entities with the appropriate level of substance in Mauritius in order not to jeopardise their residency status. This work thus contributes to existing knowledge on Mauritius as a treaty based jurisdiction.

\subsection{Recommendations}

For the long term sustainability of the Global Business Licence 1 through the use of Double Taxation Avoidance Agreement, stringent legal and regulatory frameworks, which are internationally recognized, need to be implemented in order to prevent the misuse of the treaties and combat money laundering. The regulators within the financial services industry should continuously consolidate their efforts to upgrade and embrace international norms and standards set by leading organisations, thereby building towards a genuinely sustainable financial centre. In reviewing the literature, it was found that agreements can always be renegotiations which may be triggered by unforeseen changes in the underlying relationship of the game (Barrett, 2003). It will therefore be important that the Mauritian authorities address the concerns of member countries while ensuring that the treaty remains commercially viable.

Criticisms against abuses of treaties have focused on the activities of the board and the lack of commercial substance in the home country. There has been and continues to be uncertainties concerning the provisions of permanent establishment and concept of residency. It is henceforth very important that authorities agree on clear guidelines and that there are no interpretation differences and no ambiguities regarding its operations. Depending on the company's function, it might be necessary to ensure more Mauritian-based substance than the basic requirements for central management, in order for it to be recognized by treaty partners as being tax resident in Mauritius. New commercial substance requirements will most probably have an impact on the tax residence status in Mauritius. In fact, Mauritius' effort must be to maintain the country's standing as an international financial centre, which hinges largely on it improving what it does in terms of transparency and making sure that companies based in Mauritius have substance.

\section{References}

Barthel, F., Busse, M., \& Neumayer, E. (2010). The Impact of Double Taxation Treaties on Foreign Direct Investment: Evidence From Large Dyadic Panel Data. Contemporary economic policy, 28(3). 366-377. https://doi.org/10.1111/j.1465-7287.2009.00185.x 
Barthel, F., Busse, M., Krever, R., \& Neumayer, E. (2010). Tax Treaties: Building between Law and Economics. Amsterdam: IBFD.

Bauman, R. E. (2007). The Complete Guide to Offshore Residency, Dual Citizenship \& Second Passports. 6th ed. USA: The Sovereign Society Ltd.

Borrego, F. A. V. (2006). Limitations On Benefits Clauses In Double Taxation Conventions. Spain: Instituto de Estudios Fiscales, Eucotax Kluwer Law International.

Brauner, Y., Stewart, M., ed. (2013). Tax, Law And Development. United Kingdom: Edward Elgar Publishing Limited. https://doi.org/10.4337/9780857930026

Campbell, D. (2008). International Taxation of Low-Tax Transactions. USD: Yorkhill Law Publishing.

Christians, D. A. (2005). Tax Treaties For Investment And Aid To Sub-Saharan Africa: A Case Study. United States: Northwestern University School of Law.

Creceru, L. B. (2005). Treaty Shopping And The Abuse Of Income Tax Conventions. Canada: McGill University.

Forbes India. (2016). India-Mauritius tax treaty: An end and a new beginning.[online] Available:

http://www.forbesindia.com/blog/economy-policy/india-mauritius-tax-treaty-an-end-and-a-ne w-beginning/ (March 26, 2018).

Frankel, J. (2010). Mauritius: African Success Story. HKS Faculty Research Working Paper Series RWP10-036, John F. Kennedy School of Government, Harvard University. https://doi.org/10.3386/w16569

Gowrea, G. (2009). Mauritius: not a tax haven and white listed by Organisation for Economic Co-operation and Development, International Tax Review, 20(5).

Henriques, A., \& Richardson, J. (2004). The Tripple Bottom Line: Does It All Add UP? Assessing The Sustainability Of Business and CSR. United Kingdom: Earthscan.

Imam, P., \& Minoiu, C. (2008). Mauritius: A Competitiveness Assessment. IMF Working Paper WP/08/212, IMF African Department.

Le Mauricien. (2015). The Double Tax Avoidance Treaty with India: End of Negotiations... And Beginning Of Derailment of the Global Business Sector? Le Mauricien, 7 July.

Lessambo, I. F. (2009). Taxation Of International Business Transactions. Australia: iUniverse Inc.

Maisto, G., ed. (2006). Tax Treaties And Domestic Law. Amsterdam: IBFD Publications BV.

Malhotra, N. K. (2004). Marketing research: an applied orientation. 4th ed. Upper Saddle River, NJ: Pearson/Prentice Hall.

Mondaq. (2012). Mauritius: Mauritius Budget 2013: Attracting Investors, or Scaring Them 
Away? [online] Available:

http://www.mondaq.com/x/211222/offshore+financial+centres/Mauritius+Budget+2013+Attr acting+Investors+Or+Scaring+Them+Away (July 9, 2013).

Monsen, E. R. (1992). Research: Successful Approaches. Georgia: Athens.

Nayak, R., \& Pai, G. (2010). Ruling on the taxability of capital gains under the India-Mauritius Tax Treaty, International Tax Review, 21(4).

News on Sunday. (2013). [Diaporama] Global Business: An impending death?[online] Avilable: https://defimedia.info/global-business-impending-death (March 26, 2018).

Rao, S., \& Nayak, R. (2010). India poses holding company challenges", International Tax Review, Vol. 21, Issue 5.

Stampini, M., Leung, R., Diarra, M. S., \& Pla, L. (2011). How Large Is The Private Sector In Africa? Evidence From National Accounts and Labour Markets. Germany: IZA.

The Economic Times. (2013). End of Tax Treaty with India to hit Mauritius: IMF. [online] Available:http://articles.economictimes.indiatimes.com/2013-04-16/news/38586449_1_mauri tius-dtac-double-taxation-avoidance-convention-tax-treaty (June 12, 2013).

The Economic Times. (2013). India awaiting Mauritius response for tax treaty revision. [online] Available:

http://articles.economictimes.indiatimes.com/2013-08-27/news/41499227_1_indian-ocean-ta $\mathrm{x}$-treaty-revision-double-taxation-avoidance-convention (June 12, 2013).

The Lawyer. (2013). Offshore special- Mauritius: Sun, sea and tax. [online] Available: http://www.thelawyer.com/analysis/market-analysis/regions/offshore-analysis/offshore-specia 1-mauritius-sun-sea-and-tax/3007240.article (July 12, 2013).

Yang, Y., \& Gupta, S. (2005). Regional Trade Arrangements In Africa: Past Performance And The Way Forward. IMF Working Paper WP/05/36, IMF African Department.

https://doi.org/10.5089/9781451860559.001

\section{Copyright Disclaimer}

Copyright for this article is retained by the author(s), with first publication rights granted to the journal.

This is an open-access article distributed under the terms and conditions of the Creative Commons Attribution license (http://creativecommons.org/licenses/by/3.0/). 